\title{
Rare Malignancies of the Female Genital Tract
}

\author{
Rijuta Joshi, Gehanath Baral \\ Department of Obstetrics and Gynecology, Paropakar Maternity and Women's Hospital, Kathmandu
}

Received: March 31, 2020

Accepted: May 5, 2020

\section{ABSTRACT}

Aims: To analyze rare female genital tract malignancies.

Method: This is retrospective descriptive study as a census of all rare female genital tract malignancies in two years from 2017 to 2019 at Paropakar Maternity and Women's Hospital in Kathmandu. Data were retrieved from medical record and entered into Microsoft Excel and SPSS 16 window for analysis.

Results: There were 156 cases of female genital tract malignancies including 128 common types and 28 rare types. Majority fell under 41 50 years $(n=44 ; 28.2 \%)$ followed by over $60(n=41 ; 26.2 \%)$ and $51-60$ years $(n=34 ; 21.8 \%)$. Among ovarian tumors, the rare varieties were adult granulosa cell tumor $(n=4)$, immature teratoma $(n=3)$ and single case each of yolk sac tumor, dysgerminoma, malignant mixed germ cell tumor, carcinoid tumor, juvenile granulosa cell and sertoli cell tumor. There were one case each of carcinosarcoma, serous carcinoma and endometrial stromal carcinoma; two cases each of leiomyosarcoma and choriocarcinoma while there was a single case of placental site trophoblastic tumor. The rare cervical malignancies were small cell $(n=2)$, and clear cell carcinoma $(n=1)$. There were single cases each of basal cell carcinoma of vulva, verrucus carcinoma, fibromyxoid sarcoma of Bartholin's gland and malignant melanoma of vagina.

Conclusion: Rare female genital tract cancers were found mostly from the ovary followed by uterus; $18 \%$ of total cancers were rare types.

Key words: female, genital tract, rare malignancy

Citation : Joshi R, Baral G. Rare Malignancies of the Female Genital Tract. Nep J Obstet Gynecol. 2020;15(30):18-23. DOI: 10.3126/ njog.v15i1.29334

\section{INTRODUCTION}

Among non-communicable diseases, cancer is the first or second leading cause of death under 70 years of age in majority of countries (91/172). ${ }^{1}$ In females, breast cancer is the commonest cancer and also the leading cause of cancer death while cervical cancer is the fourth one in both incidence and mortality. Among new cases in 2018, cancer of cervix, corpus uteri, ovary, vulva and vagina were common in that order. ${ }^{2}$ Cancer registry is poor and cancer management is challenged by health care delivery system and socioeconomic conditions. ${ }^{1,3}$

Cervical, ovarian and endometrial cancers are the common sites followed by vulva, vagina and fallopian tubes in female genital tract.4-6 Among carcinoma of cervix, squamous cell carcinoma (SCC) is common type while rare types are neuroendocrine, carcinosarcoma, lymphoma and melanoma., ${ }^{4,5}$

\section{CORRESPONDENCE}

Dr Rijuta Joshi

Paropakar Maternity and Women's Hospital, Kathmandu

Email: dr.rijutajoshijha@yahoo.com; Mobile: +977-9851151830
The majority of the malignant ovarian tumors are epithelial in origin $(90 \%))^{4,5}$ Ovarian germ cell tumors (OGCT) are the rare tumors accounting for $1-2 \%$ of ovarian malignancies while sex-cord-stromal tumors (SCST) comprise 5-10\%. ${ }^{8}$ Endometroid adenocarcinoma is commonest type of endometrial cancer while other uncommon histological types are uterine papillary serous and clear cell carcinoma. ${ }^{5,9}$ Sarcoma of uterus are relatively rare and account for $3-8 \%$ of uterine cancers. ${ }^{10}$ Placental site trophoblastic tumors (PSTT) and epitheloid trophoblastic tumor are rarer than invasive mole or gestational choriocarcinoma. ${ }^{11}$ Vulval cancers are relatively rare (4\%) commonest being SCC (95\%) followed by malignant melanoma, undifferentiated carcinoma, sarcoma, basal cell carcinoma (BCC), Bartholin gland adenocarcinoma. ${ }^{5,12}$ Primary vaginal cancer is also rare $(3 \%)$ and $\mathrm{SCC}$ is the commonest type followed by adenocarcinoma, melanoma and sarcoma. ${ }^{5,13}$ 
Female genital oncosurgeries as definite treatment are increasing at study site from 30 out of 76 in $2017 / 2018$ to 52 out of 80 in 2018/2019 including rare types of cancers. ${ }^{14}$ Thus the aim is to analyze rare malignancies only during this period.

\section{METHODOLOGY}

It is a hospital based retrospective descriptive study conducted in the Departments of Obstetrics/ Gynecology and Pathology at Paropakar Maternity and Women's Hospital in Kathmandu for two year (2017-2019). Data were retrieved from hospital records, pathology database and cancer registry sites. Study variables were cancer diagnosis, age, menopausal status, clinical symptoms, stage, site, histopathology and the procedure performed. Data were entered into Microsoft Excel work book 2007 and exported to the SPSS 16 for the descriptive analysis.

\section{RESULTS}

There were 156 female genital tract malignancies (128 common and 28 rare types). Half of them were from cervix followed by ovary and endometrium. More than $75 \%$ of cervical cancer were after 40 years; ovarian cancers were equal before and after 40; and almost all endometrial cancers found after 40 [Table-1].

Table-1: Frequency distribution of malignant cases by organ of origin and age in years

\begin{tabular}{|c|c|c|c|c|c|c|c|c|c|}
\hline & จิ & 产 & $\frac{P}{\frac{\theta}{m}}$ & $\begin{array}{l}8 \\
\frac{1}{7} \\
\end{array}$ & $\frac{8}{8}$ & $\begin{array}{l}8 \\
1\end{array}$ & $\underbrace{e}_{\omega}$ & 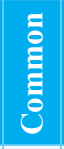 & $\stackrel{\mathscr{E}}{\check{E}}$ \\
\hline Cervix & 0 & 3 & 10 & 24 & 18 & 25 & $\begin{array}{c}80 \\
(51.3 \%)\end{array}$ & 77 & 3 \\
\hline Ovary & 4 & 11 & 5 & 8 & 9 & 4 & $\begin{array}{c}41 \\
(26.2 \%)\end{array}$ & 28 & 13 \\
\hline Endometrium & 0 & 0 & 1 & 7 & 5 & 9 & $\begin{array}{c}22 \\
(14.1 \%)\end{array}$ & 19 & 3 \\
\hline Vulva & 0 & 0 & 1 & 2 & 0 & 3 & $\begin{array}{c}6 \\
(3.8 \%)\end{array}$ & 3 & 3 \\
\hline GTD & 0 & 0 & 0 & 2 & 2 & 0 & $\begin{array}{c}4 \\
(2.6 \%)\end{array}$ & 1 & 3 \\
\hline Myometrium & 0 & 1 & 0 & 1 & 0 & 0 & $\begin{array}{c}2 \\
(1.3 \%)\end{array}$ & 0 & 2 \\
\hline Vagina & 0 & 0 & 1 & 0 & 0 & 0 & $\begin{array}{c}1 \\
(0.6 \%)\end{array}$ & 0 & 1 \\
\hline Total & 4 & 15 & 18 & 44 & 34 & 41 & 156 & 128 & 28 \\
\hline
\end{tabular}

In ovarian malignancy, majority were epithelial in origin $(n=27)$. Among the 7 OGCT, there were three cases each of immature teratoma and single case each of YST (had Schiller Duval Bodies), Dysgerminoma, mixed type and carcinoid tumor. In SCST, four cases were adult granulosa cell tumor and single case each of juvenile granulosa cell and sertoli cell tumor. Endometroid adenocarcinoma was the commonest endometrial cancer $(n=19)$ while the rare varieties were one case each of carcinosarcoma, serous carcinoma, endometrial stromal carcinoma. Among cervical malignancy, more than $80 \%$ were SCC $(n=66)$ and rare varieties were two cases of small cell and one case of clear cell carcinoma. In vulval carcinoma, SCC was most common (3/6) while there were single cases each of BCC, Verrucus carcinoma and Fibromyxoid sarcoma of Bartholin's gland. Among the rare malignancies, majority of OGCT belonged to 21-30 years (5/7) and all of them were premenopausal. Among five uterine corpus malignancies, three cases were in 50-60 years and one case each in 21-30 years and $>60$ years age group. All cases of gestational trophoblastic neoplasia (GTN) were in 41-51 years while all three cases of cervical carcinoma, were in 40-50 years. In vulval malignancy, two were at 41-50 years with single case in 31-40 years age group [Table-1 and 2].

Table-2: Profile of rare types of genital tract malignancies $(\mathrm{N}=\mathbf{2 8})$

\begin{tabular}{|c|c|c|c|c|}
\hline 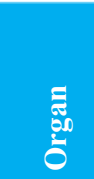 & 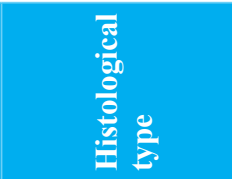 & $\frac{8}{4}$ & 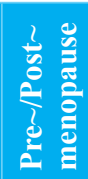 & 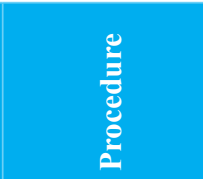 \\
\hline \multirow[t]{8}{*}{ Ovary } & $\begin{array}{l}\text { Mixed germ cell } \\
\text { tumor }\end{array}$ & 24 & Pre & $\begin{array}{l}\text { Oophorectomy } \\
+ \text { PLND + } \\
\text { PALND }\end{array}$ \\
\hline & $\begin{array}{l}\text { Yolk sac tumor } \\
\text { (YST) }\end{array}$ & 23 & Pre & $\begin{array}{l}\text { Staging } \\
\text { laparotomy }\end{array}$ \\
\hline & Dysgerminoma & 21 & Pre & $\begin{array}{l}\text { Staging } \\
\text { laparotomy + } \\
\text { LSO }\end{array}$ \\
\hline & Carcinoid tumor & 41 & Pre & TAH with BSO \\
\hline & \multirow{3}{*}{$\begin{array}{l}\text { Immature } \\
\text { teratoma (IT) }\end{array}$} & 22 & Pre & Oophorectomy \\
\hline & & 12 & Pre & Oophorectomy \\
\hline & & 26 & Pre & $\begin{array}{l}\text { Salphingo- } \\
\text { ophorectomy + } \\
\text { PLND }\end{array}$ \\
\hline & $\begin{array}{l}\text { Juvenile } \\
\text { granulosa cell }\end{array}$ & 23 & Pre & $\begin{array}{l}\text { Salphingo- } \\
\text { ophorectomy }\end{array}$ \\
\hline
\end{tabular}




\begin{tabular}{|c|c|c|c|c|}
\hline 馬 & 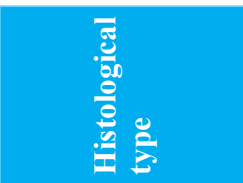 & $\underset{8}{8}$ & 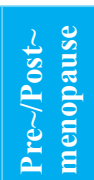 & 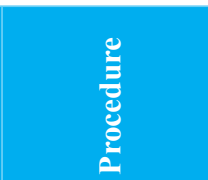 \\
\hline & \multirow{4}{*}{$\begin{array}{l}\text { Adult granulosa } \\
\text { cell (4) }\end{array}$} & 51 & Post & TAH/BSO \\
\hline & & 49 & Pre & TAH/BSO \\
\hline & & 33 & Pre & $\begin{array}{l}\text { Salphingo- } \\
\text { ophorectomy }\end{array}$ \\
\hline & & 76 & Post & $\begin{array}{l}\text { TAH, BSO + } \\
\text { appendectomy }\end{array}$ \\
\hline & Sertoli cell tumor & 68 & Post & TAH with BSO \\
\hline \multirow{5}{*}{$\begin{array}{l}\text { Uterine } \\
\text { corpus }\end{array}$} & Carcinosarcoma & 68 & Post & Biopsy \\
\hline & Serous carcinoma & 60 & Post & Biopsy \\
\hline & $\begin{array}{l}\text { Endometrial } \\
\text { stromal sarcoma } \\
\text { (ESS) }\end{array}$ & 50 & Pre & $\begin{array}{l}\text { TAH/BSO + } \\
\text { PLND }\end{array}$ \\
\hline & \multirow[t]{2}{*}{$\begin{array}{l}\text { Leiomyosarcoma } \\
\text { (LMS) }\end{array}$} & 28 & Pre & $\begin{array}{l}\text { Subtotal } \\
\text { hysterectomy }\end{array}$ \\
\hline & & 50 & Post $\sim$ & TAH/BSO \\
\hline \multirow[t]{3}{*}{ Cervix } & \multirow[t]{2}{*}{ Small cell (2) } & 50 & Post & Biopsy \\
\hline & & 40 & Pre & $\begin{array}{l}\text { Radical } \\
\text { hysterectomy }\end{array}$ \\
\hline & Clear cell & 50 & Post & Biopsy \\
\hline \multirow[t]{3}{*}{ GTN } & PSTT & 43 & Pre & TAH/BSO \\
\hline & \multirow{2}{*}{$\begin{array}{l}\text { Choriocarcinoma } \\
\text { (2) }\end{array}$} & 45 & Pre & TAH/BSO \\
\hline & & 51 & Pre & TAH/BSO \\
\hline \multirow[t]{3}{*}{ Vulva } & $\begin{array}{l}\text { Verrucus } \\
\text { carcinoma with } \\
\text { Lichen Sclerosis }\end{array}$ & 47 & Post & $\begin{array}{l}\text { Total } \\
\text { Vulvectomy }\end{array}$ \\
\hline & $\begin{array}{l}\text { Basal cell } \\
\text { carcinoma }\end{array}$ & 50 & Post & Biopsy \\
\hline & $\begin{array}{l}\text { Fibromyxoid } \\
\text { sarcoma } \\
\text { (Bartholin) }\end{array}$ & 31 & Pre & Excision \\
\hline Vagina & $\begin{array}{l}\text { Malignant } \\
\text { melanoma }\end{array}$ & 40 & Pre & Biopsy \\
\hline
\end{tabular}

\section{DISCUSSION}

In this study, $63.6 \%(7 / 11)$ of the ovarian malignancies in 21-30 years age group were OGCT which is comparable to other studies. ${ }^{15,16}$ Immature teratoma (IT) consists of immature neural elements which may be mixed with mature elements. It is commonly seen in $1^{\text {st }}$ two decades of life which is also seen in this study. ${ }^{8}$ These tumor are usually unilateral and fertility preserving surgery is primary modality of treatment. ${ }^{8,16,17}$ All of them were more than grade I and received adjuvant chemotherapy. In a study, some had mixed histology (4/20) with YST and Dysgerminoma and their mean age of 27 years is comparable to this study. ${ }^{18}$ Mixed OGCT contains at least two germ cell elements with dysgerminoma as the most common component. ${ }^{8}$ As in this study, there were similar combination in other cases. ${ }^{19-21}$ Dysgerminoma accounts for $1-2 \%$ of primary ovarian neoplasm and occur in adolescence / early adulthood. ${ }^{8}$ It can be associated with pregnancy. ${ }^{22}$ In review of 65 dysgerminomas, mean age of 22.2 years was seen which is similar to this study. ${ }^{23}$ YST can present with acute symptoms and rapid intra-abdominal spread. ${ }^{8,24}$ In this study, the YST had Schiller Duval Bodies similar to other cases. ${ }^{25}$ Primary carcinoid tumor of the ovary is uncommon and can arise within the mature cystic ovary/ mucinous tumor or as metastasis from gastro-intestinal tract. ${ }^{8,26-28}$ Sometimes there may be contra-lateral mature cystic teratoma as seen in this study. ${ }^{26}$

SCST are hormone producing tumors arising from the cells of gonadal sex cords or stromal cells and $70 \%$ are granulosa cell tumors. ${ }^{8,29}$ Sertoli-Leydig cell tumor are usually seen in young women with virilization. ${ }^{8}$ As in this study some cases are seen in postmenopausal women with vaginal bleeding..$^{30,31}$ Among two subtypes of granulosa cell tumor, 95\% are adult type occurring in middle aged / postmenopausal women and rest are juvenile type which occur in early third decades as in this study. ${ }^{8,32}$ Similar to this study, acute presentation has been reported in some cases. ${ }^{8}$ Adult granulosa cell commonly presents with vaginal bleeding due to estrogen production as seen in this study. ${ }^{8,32,33}$ The classical coffee-bean grooved cells were seen in all the cases while Call-Exner bodies were seen in two cases.

Small cell carcinoma arises from endocervical argyrophil or multipotential neuroendocrine cells and constitute $<5 \%$ of cervical cancer. ${ }^{7,34}$ They have poor prognosis due to early and frequent nodal / distant metastasis and should be differentiated from poorly differentiated SCC with neuroendocrine features. ${ }^{7}$ In a study, mean age was 45 years similar to this study. ${ }^{35}$ In a systemic review of cervical neuroendocrine carcinoma, $80 \%$ had small cell type. ${ }^{36}$ Clear cell carcinoma has been attributed to in-utero exposure of diethyl-stilbestrol (DES). Similar to this study case report of clear cell carcinoma of cervix has been seen 
in postmenopausal women without DES exposure. ${ }^{37}$ In a retrospective analysis, median age was 53 years and commonest presentation was vaginal bleeding $(12 / 18) .^{38}$

Uterine sarcoma can arise from endometrial mesenchymal tissue as endometrial stromal sarcoma (ESS) or uterine smooth muscle as leiomyosarcoma (LMS). ${ }^{10,39,40}$ In a study, mean age was 54 years and $73 \%$ (n-80) were in stage $\mathrm{I}^{40}$ In another study, there was preoperative suspicion in 20 patients. ${ }^{41}$ In this study, both cases were diagnosed as LMS postoperatively and were limited to uterus. ESS have sheets of cells which resemble endometrial stromal cells of proliferative endometrium. ${ }^{10,41}$ Commonest presentation is irregular vaginal bleeding with polypoid uterine mass while asymptomatic uterine enlargement and pelvic pain are also common as seen in this study. ${ }^{10}$

There are multiple theories regarding uterine carcinosarcoma and extra-uterine spread of carcinsarcoma is common. ${ }^{9,42}$ As in this study, it is seen in postmenopausal elderly female with bloody/ watery discharge, abdominal pain, and/or mass. ${ }^{9,43}$ Obesity, hypertension, diabetes, nulliparity, and/ or pyometra may be associated with it. ${ }^{43}$ In a study, 21/38 had carcinosarcomas while 7 had LMS and 2 had rhabdomyosarcoma. ${ }^{44}$ Uterine papillary serous endometrial carcinoma is aggressive malignancy which has intra-epithelial precancerous phase but is associated with higher stage at presentation, early recurrence and poor prognosis even in early stages. . $^{9,45,46}$

Choriocarcinoma has abnormal syncytiotrophoblast, cytotrophoblast, necrosis and hemorrhage. ${ }^{11}$ It usually arise in uterine cavity after a non-molar pregnancy and may invade through the uterus to the surrounding tissues while distant metastasis is also common. ${ }^{47,48}$ Usually they present with prolonged irregular vaginal bleeding as seen in this study while some can have unusual presentaions. ${ }^{49}$ PSTT is usually seen after term pregnancy / spontaneous abortion and must be differentiated from the choriocarcinoma / sarcomas. ${ }^{11,51}$ It produces low levels of $\beta$-hCG and does not reflect the tumor burden and malignant behavior. ${ }^{52}$ Primary hysterectomy is the modality of treatment, however some still require adjuvant chemotherapy and/or radiation for complete remission as seen in this study. ${ }^{11,52,53}$

Verrucus carcinoma is an unusual variant of SCC coined by Ackerman which constitute $<1 \%$ of vulvar cancers. $^{54,55}$ It presents as warty fungating mass in skin / mucous membrane and oral cavity is the commonest site. ${ }^{12,56,57}$ They have hyper-keratinized undulating warty surface with pushing border that compresses the surrounding tissue without true stromal invasion. ${ }^{58}$ They are locally destructive by direct invasion and lymphatic dissemination is very rare so its management differs from other vulval cancers. ${ }^{12}$ BCC comprises $1.4 \%$ of vulvar cancers which presents as a slowly growing locally invasive lesion with rolled pearly border that bleeds and heals spontaneously. ${ }^{12}$ Similar to this study, it is seen in postmenopausal women. ${ }^{59,60}$ Wide local excision with primary closure is usually done as the lymphatic involvement and metastasis is rare. ${ }^{12}$ Primary Bartholin's gland carcinoma accounts for $<5 \%$ of vulvar carcinomas and all most half them are SCC. ${ }^{12,61}$ Low grade fibro-myxoid sarcoma is very rare at vulva and present as painless slow growing mass. ${ }^{62,63}$ Radical excision and long term follow up is indicated as late metastasis can occur. ${ }^{63}$

Malignant melanoma arises from melanocytes of skin/mucous membranes and around 3\% involves the female genital tract. ${ }^{13,64}$ It is the second commonest malignancy in vulva while that of the vagina is very rare $(<0.5 \%)$ where it arises from the aberrant melanocytes. ${ }^{13,64,65}$ The commonest symptom is vaginal bleeding in a post menopausal women and blue/black lesion or mass as seen in this study. ${ }^{13}$ Early hematogenous spread is common and surgery is the primary modality of treatment. ${ }^{13,64,66}$

\section{CONCLUSION}

Out of 156 malignant tumor of female genital tract $28(18 \%)$ had rare histopathology in two years. Almost half of them were ovarian in origin such as adult granulosa cell tumor and immature teratoma. Sarcomatous lesions were common in uterus and two small cell cancer in cervix. 


\section{REFERENCES}

1. Bray F, Ferlay J, Soerjomataram I, Siegel RL, Torre LA, Jemal A. Global cancer statistics 2018: GLOBOCAN estimates of incidence and mortality worldwide for 36 cancers in 185 countries. CA: a cancer journal for clinicians. 2018;68(6):394 424.

2. World Fact Sheets. World Health Organization; 2018.

3. Subedi KS, Sharma P. Cancer treatment in Nepal: a historical background, development of treatment facilities, epidemiology and challenges for prevention and control of cancer. Austral - Asian J Cancer. 2012;11(3):205-11.

4. Joshi R, Baral G, Malla K. Malignant Tumors of the Female Genital Tract-a Hospital Based Analysis. Nep J Obstet Gynaecol. 2015;10(2):24-8.

5. Narula R, Arya A, Narula K, Agarwal K, Agarwal A, Singh S. Overview of benign and malignant tumors of female genital tract. J App Pharma Sci. 2013;3(01):140-9.

6. Poudel KK, Huang Z, Neupane PR, Steel R, Poudel JK. Hospital-Based Cancer Incidence in Nepal from 2010 to 2013. Nep J Epidem. 2017;7(1):659.

7. Tewari KS, Monk BJ. Invasive cervical cancer. In: DI Saia PJ, Creasman WT, editors. Clinical gynecologic oncology. 9th ed. Elsiver; 1012.p.38-104

8. Penick ER, Hamilton CA, Maxwell GL, Marcus CS. Germ cell, stromal and other ovarian tumors. In: DI Saia PJ, Creasman WT, editors. Clinical gynecologic oncology. 9th ed. Elsiver; 1012.p.290-313.

9. Creasman WT, Miller DS. Adenocarcinoma of uterine corpus. In: DI Saia PJ, Creasman WT, editors. Clinical gynecologic oncology. 9th ed. Elsiver;1012.p.121-54

10. Mc Meekin DS, Creasrman WT. Sarcoma of the uterus. In: DI Saia PJ, Creasman WT, editors. Clinical gynecologic oncology. 9th ed. Elsiver; 1012.p.155-62.

11. Barber EL, Soper JT. Gestational Trophoblastic Disease. In: DI Saia PJ, Creasman WT, editors. Clinical gynecologic oncology. 9th ed. Elsiver. 1012.p.163-89.

12. Herzog TJ. Invasive Cancer of the Vulva. In: DI Saia PJ, Creasman WT, editors. Clinical gynecologic oncology. 9th ed. Elsiver; 1012.p.191-216.

13. Huang M, Slomovitz BM, Coleman RL. Invasive cancer of vagina. In: DI Saia PJ, Creasman WT, editors. Clinical gynecologic oncology. 9th ed. Elsiver; 1012.p.217-30.

14. Paropakar Maternity and Women's Hospital. SMARIKA. Kathmandu: 2018;60:4

15. Tiwary B, Sinha HH, Pandey VK. Malignant mixed germ cell tumor of ovary: a rare case report. Int J Reprod Contracept Obstet Gynecol. 2015;4:511-3.

16. Shaaban AM, Rezvani M, Elsayes KM, Baskin Jr H, Mourad A, Foster BR, Jarboe EA, Menias CO. Ovarian malignant germ cell tumors: cellular classification and clinical and imaging features. Radiographics. 2014;34(3):777-801

17. Stavrou S, Domali E, Paraoulakis I, Haidopoulos D, Thomakos N, Loutradis D et al. Immature ovarian teratoma in a 21 year-old woman: a case report and review of the literature. J Gen Pract. 2016;4:232.

18. Alwazzan AB, Popowich S, Dean E, Robinson C, Lotocki R, Altman AD. Pure immature teratoma of the ovary in adults: thirty-year experience of a single tertiary care center. Int J Gynecol Cancer. 2015;1;25(9):1616-22.

19. Gaurish SK, Avinash J, Hardas S, Kulkarni MM, Barpande
CP. Ovarian malignant mixed germ cell tumor: a rare combination with five germ cell components. Indian J Pathol Microbiol. 2016;59:122-3

20. Goyal LD, Kaur S, Kawatra K. Malignant mixed germ cell tumour of ovary-an unusual combination and review of literature. J Ovarian Res. 2014;7(1):91.

21. Tiwary B, Sinha HH, Pandey VK. Malignant mixed germ cell tumor of ovary: a rare case report. Int $\mathrm{J}$ Reprod Contracept Obstet Gynecol. 2015;4:511-3.

22. Chen Y, Luo Y, Han C, Tian W, Yang W, Wang Y, Xue F. Ovarian dysgerminoma in pregnancy: a case report and literature review. Cancer Biol Ther. 2018;19(8):649-58.

23. Vicus D, Beiner ME, Klachook S, Le LW, Laframboise S, Mac kay H. Pure dysgerminoma of the ovary 35 years on: a single institutional experience. Gynecol Oncol. 2010;117(1):23-6.

24. Jain AJ, Daver RG, Patil AM. Huge yolk sac tumor in an adolescent girl: a case report. Int J Reprod Contracept Obstet Gynecol. 2017;6:3192-4.

25. Eddaoualline H, Sami H, Rais H, Belbaraka R, El Omrani A, Khouchani M. Ovarian Yolk sac tumor: a case report and literature review. Clin Case Rep Int. 2018; 2:1057.

26. Salhi H, Laamouri B, Boujelbène N, Hassouna JB, Dhiab T, Hechiche M, Rahal K. Primary ovarian carcinoid tumor: a report of 4 cases. Int Surg J. 2017;4:2826-8.

27. Orsi NM, Menon M. Primary ovarian neuroendocrine tumo arising in association with a mature cystic teratoma: a case report. Gynecol Oncol Rep. 2016;17:83-5.

28. Gonzalez MD, Navarrete SV, Pena RJ. Primary ovarian carcinoid tumor arising within a mature cystic teratoma in a 32-years-old patient. Gynecol Reproduct Endocrinol-UK. 2018; 2 (1): 2-4.

29. Haroon S, Zia A, Idrees R, Memon A, Fatima, Kayani N Clinicopathological spectrum of ovarian sex cord-stromal tumors; 20 years' retrospective study in a developing country. J Ovarian Res. 2013;6:87.

30. Tsuzuki Y, Kikuchi I, Nojima M, Yoshida K, Hashizume A, Tomita S. A case report: ovarian Sertoli-Leydig cell tumor with hyperestrogenism and endometrial hyperplasia in a postmenopausal woman. Jpn Clin Med. 2017;8:1179066017695239.

31. Wang L, Yao A, Zhang A, Qu P. Sertoli-Leydig cell tumor characterized by hyperestrogenism in a postmenopausal woman: a case report and review of the literature. European J Gynaecol Oncol. $2019 ; 40(3): 502-5$

32. Horta M, Cunha TM. Sex cord-stromal tumors of the ovary: a comprehensive review and update for radiologists. Diagn Interv Radiol. 2015;21:277-86.

33. Kottarathil VD, Antony MA, Nair IR, Pavithran K. Recent advances in Granulosa Cell Tumor ovary: a review. Indian Surg Oncol. 2013;4(1):37-47.

34. van Nagell Jr JR, Powell DE, Gallion HH, Elliott DG Donaldson ES, Carpenter AE, Higgins RV, Kryscio R, Pavlik EJ. Small cell carcinoma of the uterine cervix. Cancer 1988;62(8):1586-93

35. Xu F, Ma J, Yi H, Hu H, Fan L, Wu P, Chen X, Wu X, Yu L, Xing H, Wang W. Clinicopathological aspects of Small Cell neuroendocrine carcinoma of the uterine cervix: a multicenter retrospective study and meta-analysis. Cell Physiol Biochem. 2018;50(3):1113-22

36. Tempfer CB, Tischoff I, Dogan A, Hilal Z, Schultheis B, Kern P, Rezniczek GA. Neuroendocrine carcinoma of the 
cervix: a systematic review of the literature. BMC cancer. 2018;18(1):530.

37. Pal S, Jana S, Bose K. Clear cell carcinoma of cervix in postmenopausal woman: a case report. J Midlife Health. 2015;6(2):85.

38. Wang D, Zhao C, Fu L, Liu Y, Zhang W, Xu T. Primary clea cell adenocarcinoma of the cervix: a clinical analysis of 18 cases without exposure to Diethylstilbestrol. Obstet Gynecol Int. 2019;2019:9465375.

39. Pellanda AF, De Bari B, Deniaud-Alexandre E, Krengli M, Van Houtte P, Richetti A et al. Outcome and prognostic factors in 110 consecutive patients with primary uterine leiomyosarcoma: a rare cancer network study. Chin J Cancer Res. 2017;29(6):521.

40. Kim WY, Chang SJ, Chang KH, Yoon JH, Kim JH, Kim BG et al. Uterine leiomyosarcoma: 14-year two-center experience of 31 cases. Cancer Res Treat. 2009;41(1):24.

41. Devi PU, Himaja S, Manasa R, Atla BL. Uterine low grade endometrial stromal sarcoma: a case report with review of literature. Int J Res Med Sci. 2015;3:2510-3.

42. McCluggage WG. Malignant biphasic uterine tumours: carcinosarcomas or metaplastic carcinomas? J Clin Pathol. 2002;55(5):321-5.

43. Kanthan R, Senger JL. Uterine carcinosarcomas (malignan mixed müllerian tumours): a review with special emphasis on the controversies in management. Obstet Gynecol Int 2011;2011:470795

44. Sait HK, Anfinan NM, El Sayed ME, Alkhayyat SS, Ghanem AT, Abayazid RM, Sait KH. Uterine sarcoma: clinicopathological characteristics and outcome. Saudi Med J. 2014;35(10):1215.

45. Fadare O, Zheng W. Endometrial serous carcinoma (uterine papillary serous carcinoma): precancerous lesions and the theoretical promise of a preventive approach. Am J Cancer Res. 2012;2(3):335.

46. Kawata M, Miyoshi A, Fujikawa E, Kanao S, Takeda M, Mimura M, Nagamatsu M, Yokoi T. Serous endometrial intraepithelial carcinoma: case report and literature review. J Clin Gynecol Obstet. 2017;6(2):49-52

47. Hou MM, Xu L, Qie MR. Postmolar choriocarcinoma after an interval of 7 years: case report and literature review. Gyneco Minim Invasive Ther. 2017;6(4):207-10.

48. Ngan HY, Seckl MJ, Berkowitz RS, Xiang Y, Golfier F, Sekharan PK, Lurain JR, Massuger L. Update on the diagnosis and management of gestational trophoblastic disease. Int J Gynecol Obstet. 2018;143:79-85.

49. Mangla M, Singla D, Kaur H, Sharma S. Unusual clinical presentations of choriocarcinoma: a systematic review of case reports. Taiwan J Obstet Gynecol. 2017;56(1):1-8.

50. Zhang HY, Yue XN, Tao X, Xi ML, Yan AQ, Lu X. Placental site trophoblastic tumor presented with vaginal metastasis. Int J Clin Exp Med. 2015;8(2):2993
51. Yalinkaya A, Guzel AI, Kangal K, Buyukbayram H, Firat U. Two cases of placental site trophoblastic tumor. Taiwan J Obstet Gynecol. 2011;50(3):372-4

52. Behtash N, Ghaemmaghami F, Hasanzadeh M. Long term remission of metastatic placental site trophoblastic tumor (PSTT): case report and review of literature. World J Surg Oncol. 2005;3(1):34

53. Hou MM, Xu L, Qie MR. Postmolar choriocarcinoma after an interval of 7 years: case report and literature review. Gynecol Minim Invasive Ther. 2017;6(4):207-10.

54. Campaner AB, Cardoso FD, Fernandes GL, Veasey JV. Verrucous carcinoma of the vulva: diagnosis and treatment. An Bras Dermatol. 2017;92(2):243-5.

55. Ackerman LV. Verrucous carcinoma of the oral cavity. Surgery. 1948;23(4):670-8.

56. Kiziltan HS, Gunes Bayir A, Taspinar O, Yucesan G, Tastekin $\mathrm{D}$, Sonmez FC et al. Radioprotectant and cytotoxic effects of Spirulina in relapsed verrucous vulvar cancer: a case report. Altern Ther Health Med. 2015;21:68-72.

57. Kraus FT, Perez-Mesa C. Verrucous carcinoma. Clinical and pathologic study of 105 cases involving oral cavity, larynx and genitalia. Cancer. 1966;19(1):26-38.

58. Iavazzo C, Fotiou S, Salakos N, Bakalianou K, Kondi-Pafiti A. HPV-related verrucous carcinoma of the vulva. A case report and literature review. Eur J Gynaecol Oncol. 201;32(6):680.

59. Banda JEA, Mendes SHF, Fernandes SS, Chaves R .Basal cell carcinoma of the vulva: a case report. Obstet Gynecol Int J. 2016; 5(3): 00158

60. Caucanas M, Müller G, Vanhooteghem O. Vulvar basal cell carcinoma: report of a case involving the mucosa and review of the literature. Dermat reports. 2011;3(3):e37.

61. Bhalwal AB, Nick AM, Dos Reis R, Chen CL, Munsell MF, Ramalingam P, Salcedo MP, Ramirez PT, Sood AK, Schmeler KM. Carcinoma of the bartholin gland: a review of 33 cases. Int J Gynecol Cancer. 2016;26(4):785-9.

62. Güdücü N, Çoban İ, Başsüllü N, Gönenç G, Aydınlı K Low-grade fibromyxoid sarcoma of the vagina: a tumor, not previously reported at this site. Turk J Obstet Gynecol. 2014;11(3):196

63. Chokoeva AA, Tchernev G, Cardoso JC, Patterson JW, Dechev I, Valkanov S et al. Vulvar sarcomas: short guideline for histopathological recognition and clinical management. Int J Immunopathol Pharmacol. 2015;28(2) 178-86.

64. Gungor T, Altinkaya SO, Ozat M, Bayramoglu H, Mollamahmutoglu L. Primary malignant melanoma of the female genital tract. Taiwanese J Obstet Gynecol. 2009;48(2):169-75.

65. Rath S, Nanda SS, Singh AP, et al. Aggressive metastatic malignant melanoma of vagina: a case report. J Mol Oncol Res. 2018;2(1):3-5.

66. Chen L, Xiong YI, Wang H, Liang L, Shang H, Yan X. Malignant melanoma of the vagina: a case report and review of the literature. Oncol Lett. 2014;8(4):1585-8. 